\title{
Revenue Drivers of Women Labour in Crop Production in South East Nigeria
} https://dx.doi.org/10.4314/jae.v22i3.15

\section{Opata, Patience. I.}

Department of Agricultural Economics, University of Nigeria, Nsukka.

Email:patience.opata@unn.edu.ng

Phone:+2347066070155

Ezeibe, Adaku. B.

Center for Entrepreneurship and Development Research, University of Nigeria, Nsukka

Email: adaku.ezeibe@unn.edu.ng

Phone: +2348067321127

\section{Abstract}

This paper identified socioeconomic factors affecting their revenue from crop production. It is based on farm level data collected in South East Nigeria from 400 randomly selected farm units with women farmers. Results of the analysis show that household socioeconomic factors that increased their revenue were occupation, farm experience and household size. Participation in planting and harvesting also increased their revenue. Also, the societal constraint militating against women's revenue were lack of finance, lack of improved inputs, lack of storage facilities, lack of credit access, land tenure problem, poor road network. These observations underscored the need for special programmes that empower and recognize women especially through education, finance and information.

Keywords: Women, crop-production, resources, socio-economic, revenue, South East Nigeria.

\section{Introduction}

The international development community has recognized that agriculture is an engine of growth and poverty reduction in countries where it is the main occupation of the poor. But the agricultural sector in many developing countries is underperforming, in part because women, who represent a crucial resource in agriculture and the rural economy through their roles as farmers, labourers and entrepreneurs, almost everywhere, face more severe constraints than men in access to productive resources (Doss, 2016; Doss et al., 2011; Doss \& Morris, 2001; Ngqaleni, Makhura, \& Province, 1996).

Therefore, given that women play major roles in agriculture, a further question is what socio-economic and institutional factors influence their revenue? FAO (2010) argued that women are less efficient in labour productivity when compared with their male counterparts due to the nature of the household structure and the intra- 
Creative commons User License: CC BY-NC-ND

Abstracted by: EBSCOhost, Electronic Journals Service (EJS), Google Scholar, Journal Seek, Scientific Commons,

Food and Agricultural Organization (FAO), CABI and Scopus
Journal of Agricultural Extension

Vol. 22 (3) October, 2018

ISSN(e): 24086851; ISSN(Print); 1119944X

http://journal.aesonnigeria.org

http://www.ajol.info/index.php/iae

Email: editorinchief@aesonnigeria.org

household decision-making process in resource allocation. Their production levels are not the only areas affected but also the way business enterprises are managed which put the socio-economic characteristics of the women farmers into focus (Abdul-kareem \& Şahinli, 2018). Previous studies have concluded that if support is to be extended to crop producers in production locations, their basic characteristics are worth studying to fully understand their needs for need-driven assistance. For instance, (Agbola, 2014) stressed that, boosting agricultural production capacity of farmers requires that adequate information about the socio-economic characteristics of the farmers become part of the wider strategy to improve production. Many producers often missed out from supports due to their geographic and socioeconomic characteristics and these influence their production output levels.

Women make essential contributions to the agricultural and rural economies in all developing countries (Doss, Meinzen-Dick, Quisumbing, \& Theis, 2018). Their roles vary considerably between and within regions and are changing rapidly in many parts of the world, where economic and social forces are transforming the agricultural sector. Rural women often manage complex households and pursue multiple livelihood strategies. Their activities typically include producing agricultural crops, tending animals, processing and preparing food, working for wages in agricultural or other rural enterprises, collecting fuel and water, engaging in trade and marketing, caring for family members and maintaining their homes. Many of these activities are not defined as "economically active employment" in national accounts but they are essential to the well-being of rural households (Doss et al., 2018). Therefore, this work drew insight from gender debate and asks: what contextual factors (socioeconomic and institutional conditions) describe the revenue from women labour contribution in crop production? What crop production problems are associated with women farmers? Thus the main objective of this study is to analyze the key factors influencing the revenue derived from women labour in crop production. The findings of this study can assist policy-makers, Nigerian Federal Ministry of Women Affairs and Development, non-governmental organizations (NGOs), international organizations who will be furnished with information needed in designing strategies geared towards an increase in revenue, provision of equal right and opportunities, promotion of gender equality, rural development and poverty reduction. Interested parties will have what the drivers of revenue resulting from women labour utilization are, so that they can concentrate on them in other to increase revenue from female labour force utilization in crop production.

This study represents a departure from the generally coarse and purely descriptive approach such as frequencies, cross tabulations, mean ratios adopted in several studies investigating revenue in crop production (Ansari \& Sunetha, 2014; Dommati \& Chittedi, 2011; Villabón, 2012; Waris, Nirmala, \& Kumar, 2016). This work used econometric approach to identify and integrates socio-economic and institutional conditions that are associated with output of women labour in crop production. 
Creative commons User License: CC BY-NC-ND

Abstracted by: EBSCOhost, Electronic Journals Service (EJS),

Google Scholar, Journal Seek, Scientific Commons,

Food and Agricultural Organization (FAO), CABI and Scopus
Journal of Agricultural Extension

Vol. 22 (3) October, 2018

ISSN(e): 24086851; ISSN(Print); 1119944X

http://journal.aesonnigeria.org

http://www.ajol.info/index.php/iae

Email: editorinchief@aesonnigeria.org

\section{Methodology}

The study area is South-east geopolitical zone of Nigeria. Five states constitute this zone: Abia, Anambra, Ebonyi, Enugu, and Imo, covering latitude $4^{0} 50^{\prime} \mathrm{N}$ to $7^{0} 10^{\prime} \mathrm{N}$ and longitudes $6^{\circ} 40^{\prime} \mathrm{E}$ to $8^{0} 30^{\prime} \mathrm{E}$. The zone spreads over a total area of $78,618 \mathrm{~km}^{2}$, representing $8.5 \%$ of the nation's total land area. The area has a total population of 16,381,729, (National Population Commission, 2007).

Six-stage sampling procedure was employed for the study. In stage one, two states were randomly selected from the five states using a simple random sampling technique. The two states were Enugu and Abia. In stage two, all the three zones in Abia were selected while three zones from the six zones of Enugu states were selected using simple random technique. Zones from Abia were Aba, Umuahia and Ohafia while those from Enugu were Enugu, Awgu and Nsukka zones. Stage three involves selection of Local Government Areas, twelve rural local government areas were selected from the thirty-four Local Government Areas using random sampling techniques. Stage four involved selection of rural communities. This stage involved random selection of two rural communities from each of the twelve (12) rural Local Government Areas selected. This amounted to twenty-four (24) rural communities that were used for the study. Stage five involves selection of villages, a list of villages that make up each of the twenty-four (24) communities was gotten from the community head. From this list two (2) villages were randomly selected from each of the sampled twenty-four (24) communities. This amounted to forty-eight (48) villages. Stage six is the selection of respondents. Here, list of respondents was gotten from the village heads where there are women farmers, and from there eight or nine (8 or 9) household farmers were randomly selected from each village. This amounted to four hundred (400) household farmers. In each selected household, relevant female and male farmer were interviewed. The researcher's reason for this was because most farm lands are owned by men and women participants in the farm operations. It also helped the researcher to know the contributions made by men and women farmers in order to compare who contributed more labour in crop production.

Cross sectional data were generated from a farm survey conducted during 2015/16 crop year, and primarily involved administration of sets of structured questionnaires to respondents, including using twelve open ended questionnaires for focus group discussions in each of the Local Government Area. The survey questionnaire was duly pre-tested on a randomly selected sample of 26 respondents, in January 2015. This was subsequently followed by a pilot survey of 100 farmers (50 men and 50 women), exploring the potentials and limitations of the study (Ezeibe, Edafiogo, Okonkwo, \& Okidi, 2015). The result of the pre-test and pilot study was used in validating the survey questionnaire coverage, timing, and administration techniques adopted. 
Creative commons User License: CC BY-NC-ND

Abstracted by: EBSCOhost, Electronic Journals Service (EJS),

Google Scholar, Journal Seek, Scientific Commons,

Food and Agricultural Organization (FAO), CABI and Scopus
Journal of Agricultural Extension

Vol. 22 (3) October, 2018

ISSN(e): 24086851; ISSN(Print); 1119944X

http://journal.aesonnigeria.org

http://www.ajol.info/index.php/iae

Email: editorinchief@aesonnigeria.org

\section{Data analysis}

Data were analysed with descriptive statistics and perspective along the econometric estimation procedures using SPSS. Data were analysed using the multiple regression model. The basic multivariate model to test the effects of socio-economic and institutional variables on revenue of women farmers is stated as:

Where

$$
Y=f\left(X_{1}, X_{2}, X_{3}, X_{4}, X_{5}, X_{6}, X_{7}, X_{8}, X_{9}, X_{10}, X_{11}, X_{12}, X_{13}\right)+e
$$

$Y=$

$\mathrm{X}_{1}=$ Women labour utilization in clearing (man-days)

$\mathrm{X}_{2}=$ Women labour utilization in cultivating (man-days)

$\mathrm{X}_{3}=$ Women labour utilization in planting (man-days)

$\mathrm{X}_{4}=$ Women labour utilization in weeding (man-days)

$\mathrm{X}_{5}=$ Women labour utilization in harvesting (man-days)

$\mathrm{X}_{6}=$ Age of women farmers (years)

$\mathrm{X}_{7}=$ Farming experience (years)

$\mathrm{X}_{8}=$ Educational level (number of years spent in school)

$\mathrm{X}_{9}=$ Occupation (Dummy farming $=1$ otherwise $=0$ )

$\mathrm{X}_{10}=$ Household size (number)

$\mathrm{X}_{11}=$ Household head $($ Dummy female $=1$ otherwise $=0)$

$\mathrm{X}_{12}=$ Farm size (number of hectares)

$\mathrm{X}_{13}=$ Distance of farm from home (kilometre)

$\mathrm{e}=$ Error term

Three functional forms of the model were tried; namely linear, semi-logarithmic and double logarithmic. The double log form gave the best fit in terms of $\mathrm{R}^{2}$ value and $\mathrm{F}$ ratio and conformity with apriori expectation. It was therefore selected and used for the analysis. The double log form is expressed implicitly.

Double-Logarithmic Form

$$
\begin{aligned}
\log & Y=\log a+b_{1} \log x_{1}+b_{2} \log x_{2}+b_{3} \log x_{3}+b_{4} \log x_{4}+b_{5} \log x_{5}+ \\
& b_{6} \log x_{6}+b_{7} \log x_{7}+b_{8} \log x_{8}+b_{9} \log x_{9}+b_{10} \log x_{10}+b_{11} \log x_{11}+ \\
& b_{12} \log x_{12}+b_{13} \log x_{13}+e .
\end{aligned}
$$

The justification for inclusion of these variables is as follows. Conventionally, age and experience are directly proportional in the smallholder farmer operations. The relationship between age of farmers and their potential output levels has engaged and continued to engage at least for some time. The argument surrounding age as far as efficiency, productivity and output potentials are concern gathered momentum and show no sign of ending anytime soon. Depending on the effects of other demographic and socio-economic factors on age, it can either enhance or reduce the output levels of farmers in production process. According to some studies age influences output levels positively because farming is an activity that the farmers perfect through practice over time (Abdul-kareem \& Şahinli, 2018). Other studies conclude otherwise as young farmers being more positioned to realise higher outputs than older farmers (Samuel Debrah and Abubakari, 2014). They hold the view that 
Creative commons User License: CC BY-NC-ND

Abstracted by: EBSCOhost, Electronic Journals Service (EJS), Google Scholar, Journal Seek, Scientific Commons,

Food and Agricultural Organization (FAO), CABI and Scopus
Journal of Agricultural Extension

Vol. 22 (3) October, 2018

ISSN(e): 24086851; ISSN(Print); 1119944X

http://journal.aesonnigeria.org

http://www.ajol.info/index.php/iae

Email: editorinchief@aesonnigeria.org

older farmers may be reluctant to change and sometimes their unwillingness or inability to adopt technological innovations could affect their production abilities leading to low level of outputs realised.

Evidence from empirical studies have shown an educational level of women farmers to increase their output levels through increase knowledge of the production processes and easy understanding of research materials of new agronomic practices (Abdul-kareem \& Şahinli, 2018). Furthermore, the magnitude of time and efforts needed to convince producers to undertake innovative and improved farming practices are reduced with literate farmers. Illiterate producers are sometimes trivial and unnecessarily focused on the personality of the extension personnel rather than the message (Lagat \& Maina, 2017).

Occupation will have a positive sign if the primary occupation of the women is farming and vice versa. This is because women farmers will utilize more labour in the farm than women civil servants and others in other jobs and more revenue from farm operations.

Evidence from other research carried out in this area show the following expectation; large household size is expected to be positively related to revenue from women labour utilization. Higher number of people in a household will lead to more work in the farm and more revenue from farm operations (Raman, 2010).

The gender of household head according to studies has some production implications. Aromolaran, (2010), argued that information did not exist to identify whether the processes of allocation of human and physical capital to men and women had a bearing on any observed gender differences in productivity. For example, underinvestment in girls' education by parents in their resource allocation decisions could lead to lower probabilities of female farmers adopting new technologies and, therefore, being less efficient (Akter et al., 2017). Andrews, Golan, and Lay, (2014) further observed that inadequate specification of individual farmer characteristics contributes to the confusion between "sex and gender" as a source of productive differences. Sex differences are due to innate biological differences between men and women. Gender differences, on the other hand, arise from the socially constructed relationship between men and women. These differences affect the distribution of resources and responsibilities between men and women, and are shaped by ideological, religious, ethnic, economic, and cultural determinants (Doss et al., 2018).

More recently, there is burgeoning concerns for farm size and output level relationship. Continuously, the empirical literature is flooded with arguments for and against farm sizes in productions. Many studies have concluded that the larger farm size is preferable to smaller farm size in terms of outputs obtainable from the production process (Abdul-kareem \& Şahinli, 2018). However, findings of other investigators in the same area assert otherwise (Lowder, Skoet, and Raney, 2016). Their conclusive assertions lend credence that farms with smaller land sizes produce higher output than their larger size counterparts. There has not been a consensus on 
Creative commons User License: CC BY-NC-ND

Abstracted by: EBSCOhost, Electronic Journals Service (EJS), Google Scholar, Journal Seek, Scientific Commons,

Food and Agricultural Organization (FAO), CABI and Scopus
Journal of Agricultural Extension

Vol. 22 (3) October, 2018

ISSN(e): 24086851; ISSN(Print); 1119944X

http://journal.aesonnigeria.org

http://www.ajol.info/index.php/iae

Email: editorinchief@aesonnigeria.org

this, but quite strangely the approach adopted by researchers from both sides of the block raises more questions than it answers. Importantly, one thing that is driving the debate in a subtle manner is the productivity level of the land or the fertility level of the land under cultivation. That is to say how much is obtained from a parcel of land is a function of several factors rather than just the number of acreages engaged. Additionally, in making a case for either of them, there is always some unintended neglect of the influences of other factors of production in the production process which may lead to erroneous conclusions of one being preferable to the other (Masterson, 2007).

The distances of a farmland from the house will also determine the level of revenue from women labour. Women will work more on farmland closer to their houses like their backyards and surrounding than the farm land that is far from their houses.

The opinion of the women farmers as regards the constraints was measured with Likert-scale. Likert-type scale of a 4 point was adopted and graded as very serious = 4 , serious $=3$, not very serious $=2$ and not serious $=1$. Based on this grading, the levels of constraints facing women farmers were ranked using weighted mean. The mean score $(\bar{x})$ of respondents based on the point scale is $4+3+2+1=10 / 4=2.5$. Using the interval scale of 0.05 , the upper limit cut off point was $2.5+0.05=2.55$; the lower limit was $2.5-0.05=2.45$. Then, any mean score $(\bar{x})$ below 2.45 , was ranked as "not serious, and not very serious" while between 2.45 and 2.55 were considered as "serious", while any $\bar{x}$ greater than or equal to 2.55 was considered as "very serious" problems to farmers.

\section{Results and Discussions}

Determinants of revenue of women labour in crop production (Results of multiple regression model Double Logarithmic form)

In order to determine the effect of women labour utilization on value of output (Revenue), a multiple regression analysis was employed. Among the various functional forms (Linear, Semi-logarithmic and double logarithmic) that were tried, the double log form gave a higher $R^{2}$ values with a relatively low standard error $(0.22)$ in Table 1.

It best represented farmers experience. The signs of the coefficients were consistent with apriori expectations and also greater numbers of variables were significant. The double log was also accepted because of the significant F-ratio (2.002) and $R^{2}(0.67)$ which means that $67 \%$ of the variables of farm revenue of the women are predictable by the equation. Table 1 shows the result of the regression analysis. Apart from variables age of women farmers $\left(X_{6}\right)$, education level $\left(X_{8}\right)$, and distance of farm from home $\left(X_{13}\right)$ which had negative signs, all other variables (that is women labour utilized in clearing $\left(X_{1}\right)$, women labour utilized for cultivation $\left(X_{2}\right)$, women labour utilized for planting $\left(X_{3}\right)$, women labour utilized for weeding $\left(X_{4}\right)$, women labour utilized in harvesting $\left(X_{5}\right)$, farming experience $\left(X_{7}\right)$, occupation $\left(X_{9}\right)$, household size $\left(X_{10}\right)$, gender $\left(X_{11}\right)$ and farm size $\left(X_{12}\right)$ were positive hence they have positive effect on output. 
Creative commons User License: CC BY-NC-ND

Abstracted by: EBSCOhost, Electronic Journals Service (EJS), Google Scholar, Journal Seek, Scientific Commons,

Food and Agricultural Organization (FAO), CABI and Scopus
Journal of Agricultural Extension

Vol. 22 (3) October, 2018

ISSN(e): 24086851; ISSN(Print); 1119944X

http://journal.aesonnigeria.org

http://www.ajol.info/index.php/iae

Email: editorinchief@aesonnigeria.org

Age of the farmer had a negative relationship with their income. Its coefficient was 0.44 while t- value was 2.345 which was significant at $5 \%$ probability level. The negative coefficient of age means that as the age of the women farmers increased, their income decreases. As the farmer gets older the ability to do farm work reduces thereby reducing her income. It also implies that older women farmers might be more concerned about being food secured and would not and revenue. Musah, Bonsu, \& Seini, (2014) observed that younger farmers are expected to enhance their quality of live hence would sell excess output and increase their revenue to achieve their objectives. Also, adoption of innovation declines with increased age; the older category in the society is considered to be conservative, traditional and not amenable to change such that interest and entrepreneurship declines with increased age. This finding also agrees with Samuel, Debrah and Abubakari (2014) and reported that the major impediment to improved production is hinged on socio-economic variables of farmers for which age is most significant.

Farming experience had a positive relationship with output but was significant at $5 \%$ probability level. It implies that output increases with increase in farming experience over the years i.e. as the farmer remain in farming, they gain more experience. The significance was because majority of the farmers had many years of farming experience.

Table 1: Estimates of the determinants of revenue for women labour utilization

\begin{tabular}{lllll}
\hline & Variables & Double log & Semi log & Linear \\
\hline 1 & Clearing & $0.001(0.135) \mathrm{NS}$ & $0.977(0.429)$ & $0.697(0.506) \mathrm{NS}$ \\
2 & Cultivating & $0.001(0.135) \mathrm{NS}$ & $0.249(0.212) \mathrm{NS}$ & $0.198(0.202) \mathrm{NS}$ \\
3 & Planting & $0.004(1.968)^{\star *}$ & $3.273(2.040)^{\star *}$ & $2.495(1.758)^{\star *}$ \\
4 & Weeding & $-0.001(2.015)^{\star *}$ & $-0.646(0.580) \mathrm{NS}$ & $-0.287(0.314) \mathrm{NS}$ \\
5 & Harvesting & $0.002(1.998)^{\star *}$ & $-1.388(0.978) \mathrm{NS}$ & $-1.216(1.017) \mathrm{NS}$ \\
6 & Age & $-0.447(2.345)^{\star *}$ & $-338.168(2.367)^{\star *}$ & $-8.543(3.013)^{\star *}$ \\
7 & Experience & $0.084(2.161)^{\star *}$ & $242.291(0.868) \mathrm{NS}$ & $-1.479(0.066) \mathrm{NS}$ \\
8 & Education & $-0.025(0.655) \mathrm{NS}$ & $-22.814(0.810) \mathrm{NS}$ & $-4.961(0.216) \mathrm{NS}$ \\
9 & Occupation & $0.020(0.212)$ & $1.197(0.17) \mathrm{NS}$ & $-3.989(0.062) \mathrm{NS}$ \\
10 & Household size & $0.156(2.391)^{\star *}$ & $120.189(2.457)^{\star *}$ & $16.551(2.556)^{\star *}$ \\
11 & Household head & $0.104(1.234) \mathrm{NS}$ & $73.284(1.160) \mathrm{NS}$ & $70.080(1.323) \mathrm{NS}$ \\
12 & Farm size & $0.235(1.297)$ & $-166.062(1.314) \mathrm{NS}$ & $114.881(1.703)^{\star *}$ \\
13 & Distance & $-0.111(1.963)^{\star *}$ & $86.227(0.899) \mathrm{NS}$ & $45.338(1.143) \mathrm{NS}$ \\
& Constant & $7.22 .(6.902)^{*}$ & $1189.73(1.518) \mathrm{NS}$ & $877.540(4.111)^{*}$ \\
& R $^{2}$ & 0.665 & 0.357 & 0.422 \\
& St'd error of estimate & 0.222 & 166.590 & 153.693 \\
& F-ratio & $2.002^{* *}$ & $1.248 \mathrm{NS}$ & $1.947^{* *}$ \\
\hline
\end{tabular}

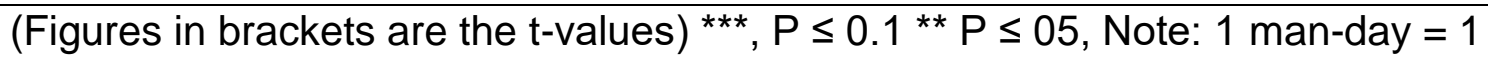
woman day; Source: Computed from field survey data, 2016

Occupation has a positive relationship with output and was not significant at $5 \%$. Given that occupation is a dummy variable with farming $=1$ and otherwise $=0$. It implies that increase in number of women farmers with farming as their primary occupation would increase participation in farming and increase income. 
Creative commons User License: CC BY-NC-ND

Abstracted by: EBSCOhost, Electronic Journals Service (EJS),

Google Scholar, Journal Seek, Scientific Commons,

Food and Agricultural Organization (FAO), CABI and Scopus
Journal of Agricultural Extension

Vol. 22 (3) October, 2018

ISSN(e): 24086851; ISSN(Print); 1119944X

http://journal.aesonnigeria.org

http://www.ajol.info/index.php/iae

Email: editorinchief@aesonnigeria.org

Household size had a positive relationship with women farmers' income $(r=0.16 ; t=$ 2.39). It implies that women farmers with larger family size would possess higher income from farming operations. This is consistent with aprori expectation that larger household size eases labour constraints thereby leading to increase in productivity and income of the household; and supports (Raman, 2010).

Distance of farm from home had a negative relationship with the women's income. Its coefficient is -0.11 while t-value is 1.963 which is significant at $5 \%$ probability level. This implies that an increase in the distance of farm from home would lead to decline in income. The significance of the variable is as a result that majority of the farmers, had their farms close to their houses.

The implication of the positive signs of coefficients of planting $X_{3}$, weeding $X_{4}$, harvesting $X_{5}$, age $X_{6}$, household size $X_{10}$, farm size $X_{12}$ is that increase in any of these variables will increase the output. They were statistically significant at $5 \%$ level. The significant relationship implies that there is sufficient evidence to claim that there is an increasing output or revenue with increase in hours spent on planting, weeding and harvesting operations. It means that women who spent more hours in the above mentioned farm operations will get more income. It is possible because planting involves replacement of non-germinated seeds and those picked by birds. Weeding involves removing those weeds that will affect crop production while harvesting is gathering the mature and ripe crops. If harvesting did not take place at the right time, birds and rodent can damage the crops thereby reducing the farm revenue.

Clearing $X_{1}$, and cultivating $X_{2}$ had a positive relationship with output but not significant.

Double logarithmic regression function was estimated for the revenue of women farmers studied and relevant null hypotheses were tested in terms of t-test and $\mathrm{F}$ tests respectively. The estimated model is summarized in Table 1. Overall, the estimated revenue is statistically significant at $5 \%$. ( $F=2.002 \geq 1.96)$. The coefficient of determination had a value of 0.67 . Indicting that $67 \%$ of the variations in the endogenous variables $(y)$ accounted for or explained by the variation in the exogenous variables (X's) while the remaining $33 \%$ was due to omitted variable and error. Showing that women labour utilization has significant effect on their revenue

Also, diagnostic test for multicollinearity and hetroscedasticity which are common problems in any regression analysis were conducted. Multi-collinearity test was conducted on variance inflation factor (VIF) to identify any potential misspecification problems that may exist in the estimated models. The test indicated that the largest VIF in the probability model is 1.96 . This value is well below the maximum value of 10 that is used as a rule of thumb to indicate the presence of multicollinearity. This implies that multicollinearity is not a problem in the estimated model. There was also no evidence of hetroschedasticity in the model as well. 
Creative commons User License: CC BY-NC-ND

Abstracted by: EBSCOhost, Electronic Journals Service (EJS),

Google Scholar, Journal Seek, Scientific Commons,

Food and Agricultural Organization (FAO), CABI and Scopus
Journal of Agricultural Extension

Vol. 22 (3) October, 2018

ISSN(e): 24086851; ISSN(Print); 1119944X

http://journal.aesonnigeria.org

http://www.ajol.info/index.php/iae

Email: editorinchief@aesonnigeria.org

\section{Farm constraints}

The opinion of the women farmers as regards the constraints they faced in crop production is presented in Table 2. The table 2 shows that 17 out of 20 constraints mentioned above were regarded as very serious problems. Lack of finance $(\bar{x}=4.0)$ was the most serious problem, implying that women farmers in this area need financial assistance to improve their income. Other farm constraints viewed very serious included lack of credit and loan $(\bar{x}=3.90)$.

In fact, productivity in farming is highly dependent on inputs needed to hire labour, purchase manure and fertilizer and inability to get it resulted to loss of crops and income for the women farmers.

Table 2: Mean distribution of farm constraints identified by women farmers

\begin{tabular}{lll}
\hline Constants & Mean & Decision \\
\hline Lack of finance & 4.00 & $* *$ \\
Lack of extension services & 2.50 & $* *$ \\
Lack of inputs & 2.90 & $* *$ \\
Lack of storage facilities & 2.90 & $* *$ \\
Lack of credit and loan & 3.90 & $* *$ \\
Lack of infrastructure & 3.00 & $* *$ \\
Negative attitude of women & 1.80 & $*$ \\
Illiteracy & 2.10 & $*$ \\
Pest and disease & 2.80 & $* *$ \\
High cost of labour & 2.83 & $* *$ \\
Transportation problem & 2.65 & $* *$ \\
Land tenure problem & 2.65 & $* *$ \\
Low motivation & 1.0 & $*$ \\
Poor and seasonal road network & 2.60 & $* *$ \\
Price fluctuation of produce & 3.20 & $* *$ \\
Difficulty in marketing produce & 3.10 & $* *$ \\
High spoilage & 3.40 & $* *$ \\
Tediousness of most farm & 2.65 & $* *$ \\
operations & & \\
Lack of mechanization of farm & 2.50 & $* *$ \\
operations & & \\
Small sized farm plots & 3.80 & $* *$ \\
\hline VS* Very Serous, NS* &
\end{tabular}

$V^{* *}=$ Very Serious, $N^{*}=$ Not Serious, Note: Multiple responses were recorded. Source: Computed from field survey data, 2016.

Akter et al., (2017) revealed that lack of financial assistance limited women's opportunity for broader participation in agriculture.

The analysis also revealed that small sized farm plots $(\bar{x}=3.80)$, high spoilage $(\bar{x}=$ $3.40)$, price fluctuation of produce $(\bar{x}=3.20)$, lack of infrastructure $(\bar{x}=3.00)$, lack of farm inputs and storage facilities $(\bar{x}=2.90)$, cost of labour $(\bar{x}=2.83)$, land tenure system and pest and disease $(\bar{x}=2.80)$, transportation constraint and technology of most farm operation $(\bar{x}=2.65)$, lack of mechanization of farm operation and lack of extension service $(\bar{x}=2.50)$ were also perceived as serious constraint militating 
Creative commons User License: CC BY-NC-ND

Abstracted by: EBSCOhost, Electronic Journals Service (EJS), Google Scholar, Journal Seek, Scientific Commons,

Food and Agricultural Organization (FAO), CABI and Scopus
Journal of Agricultural Extension

Vol. 22 (3) October, 2018

ISSN(e): 24086851; ISSN(Print); 1119944X

http://journal.aesonnigeria.org

http://www.ajol.info/index.php/iae

Email: editorinchief@aesonnigeria.org

against the production of the respondents in crop production. Illiteracy, negative attitude of women and low motivation were not serious problems and the least was low motivation with mean value of $\bar{x}=1.0$.

Most of the respondents had their farm plots scattered at different locations within and outside the village. With the poor road networks and lack of means of transportation in the rural areas, majority of the respondents spent much time and labour trekking and carrying products to and fro the farm. Again, some of the respondents sold their farm products at a time they would not have loved to do so because they could not preserve them. Since most agricultural produce are perishable items, without the necessary storage and preservative measures, some of them complained of deterioration and loss of quantity of products when they made attempt to store them.

Another area the respondents expressed as constraint was the constant changes in the price of planting materials with the unit price of planting materials such as seed yams, maize, okro, cassava cuttings among others increasing daily. Some of the respondents reported that they could no longer afford to buy them because of insufficient farm capital. They rather limit themselves to materials from previous farm work. It could be said then that all these farm production constraints identified affected productive capabilities of the respondents in their farm work.

\section{Conclusion and Recommendations}

The household socio-economic factors, identified in this study, which increased the revenue of women in crop production, were experience, occupation, household size, participation in farming activities such as planting and harvesting. In addition, the age, education, distance to the farm reduced the revenue from crop production. Also, the societal constraints militating against productivity of women in crop production were identified lack of finance, lack of extension services, lack of inputs, lack of storage facilities, lack of credit, lack of infrastructure, pest and diseases, high costs of labour, transportation problems, land tenure problems, price fluctuation. These observations underscore the need for special programmes that empower and recognise women, especially through education, finance and information

\section{References}

Abdul-kareem, M. M., \& Şahinli, M. A. (2018). Demographic and socio-economic characteristics of cassava farmers influencing output levels in the Savannah Zone of Northern Ghana. African Journal of Agricultural Research, 13(4), 189195. http://doi.org/10.5897/AJAR2017.12268

Agbola, P. O. (2014). Factors influencing food insecurity among small farmers in Nigeria. African Journal of Agricultural Research, 9(27), 2104-2110. http://doi.org/10.5897/AJAR09.710

Akter, S., Rutsaert, P., Luis, J., Me, N., Su, S., Raharjo, B., \& Pustika, A. (2017). Women' $s$ empowerment and gender equity in agriculture: A different perspective from Southeast Asia. Food Policy, 69, 270-279. http://doi.org/10.1016/j.foodpol.2017.05.003

Andrews, M. artyn, Golan, J., \& Lay, J. (2014). INEFFICIENCY OF M ALE AND F EMALE L ABOR S UPPLY IN A GRICULTURAL H OUSEHOLDS : E VIDENCE 
Creative commons User License: CC BY-NC-ND

Abstracted by: EBSCOhost, Electronic Journals Service (EJS), Google Scholar, Journal Seek, Scientific Commons,

Food and Agricultural Organization (FAO), CABI and Scopus
Journal of Agricultural Extension

Vol. 22 (3) October, 2018

ISSN(e): 24086851; ISSN(Print); 1119944X

http://journal.aesonnigeria.org

http://www.ajol.info/index.php/iae

Email: editorinchief@aesonnigeria.org

FROM U GANDA. American Journal of Agricultural Economics, 12. http://doi.org/10.1093/ajae/aau091

Ansari, M. A., \& Sunetha, S. (2014). Agriculture information needs of farm women : A study in State of north India, 9(19), 1454-1460. http://doi.org/10.5897/AJAR2014.

Aromolaran, A. B. (2010). Does increase in women' $s$ income relative to men 's income increase food calorie intake in poor households? Evidence from Nigeria. Agricultural Economics, 41, 239-249. http://doi.org/10.1111/j.15740862.2010.00442.x

DOMMATI, D., \& CHITTEDI, K. R. (2011). Employment and Wages of Agricultural Women Labor: A Case Study of Karimnagar AGRICULTURAL WOMEN LABOUR IN ANDHRA PRADESH: International Journal of Business Economics and Management Research, 2(3), 114-134.

Doss, C. (2016). Women and Agricultural Productivity: What Does the Evidence Tell Us? Yale. Retrieved from http://www.econ.yale.edu/ egcenter

Doss, C., Meinzen-Dick, R., Quisumbing, A., \& Theis, S. (2018). Women in agriculture: Four myths. Global Food Security, 16(July 2017), 69-74. http://doi.org/10.1016/j.gfs.2017.10.001

Doss, C. R., \& Morris, M. L. (2001). How does gender affect the adoption of agricultural innovations? The case of improved maize technology in Ghana. Agricultural Economics, 25, 27-39.

Doss, C., Raney, T., Anríquez, G., Croppenstedt, A., Gerosa, S., Lowde, S., ... Matuscke, I. (2011). The role of women in agriculture. Food and Agriculture Organization of the United NAtions, (11), 1-48. http://doi.org/10.1002/2014GB005021

Ezeibe, A., Oghenekevwe, D., Okonkwo, A., \& Okide, C. (2015). Gender differences and challenges in cassava production and processing in Abia State, Nigeria. African Journal of Agricultural Research, 10(22), 2259-2266. http://doi.org/10.5897/AJAR2014.8731

FAO. (2010). Gender dimensions of agricultural and rural employment: differentiated pathways out of poverty. Status, trends and gaps. Documentos de .... http://doi.org/ISBN 978-92-5-106583-9

Lagat, J. K., \& Maina, M. C. (2017). A gender and decent work analysis of cassava production and on-farm processing, in Kuria west sub- county, Kenya. African Journal of Agricultural Research, 12(31), 2533-2544. http://doi.org/10.5897/AJAR2016.12073

Lowder, S. K., Skoet, J., \& Raney, T. (2016). The Number, Size , and Distribution of Farms, Smallholder Farms, and Family Farms Worldwide q. World Development, 87, 16-29. http://doi.org/10.1016/j.worlddev.2015.10.041

Masterson, T. (2007). Productivity, Technical Efficiency, and Farm Size in Paraguayan Agriculture by Keywords: Farm Size, Productivity, Techincal Efficency , Paraguay. Working Paper. Retrieved from http://ssrn.com/abstract=964722

Musah, A. B., Bonsu, O. Y., \& Seini, W. (2014). Market participation of smallholder maize farmers in the upper west region of Ghana, 9(31), 2427-2435. http://doi.org/10.5897/AJAR2014.8545 
Creative commons User License: CC BY-NC-ND

Abstracted by: EBSCOhost, Electronic Journals Service (EJS),

Google Scholar, Journal Seek, Scientific Commons,

Food and Agricultural Organization (FAO), CABI and Scopus
Journal of Agricultural Extension Vol. 22 (3) October, 2018

ISSN(e): 24086851; ISSN(Print); 1119944X

http://journal.aesonnigeria.org

http://www.ajol.info/index.php/iae

Email: editorinchief@aesonnigeria.org

National Population Commission. Nigerian population, state by state analysis. (2007). Nigeria.

Ngqaleni, M., Makhura, M. T., \& Province, N. (1996). THE ROLE OF WOMEN IN THE RECONSTRUCTION OF AGRICULTURE IN DEVELOPING AREAS : THE CASE OF THE NORTHERN PROVINCE / DIE ROL VAN VROUE IN DIE ITHE ROLE OF WOMEN IN THE RECONSTRUCTION OFI AGRICULTURE IN DEVELOPING AREAS: THE CASE OF THE ^. Agrekon, 34(4), 221-225. http://doi.org/10.1080/03031853.1995.9524814

Raman. (2010). Women's Labour Contribution to Productivity and Efficiency in Agriculture: Emperical Evidence from Bangladesh. Journal of Agricultural Economics, 61(2), 318-342. http://doi.org/10.1111/j.1477-9552.2010.00243.x

Samuel, T. A., Debrah, I.A., Abubakari, R. (2014). Technical Efficiency of Vegetable Farmers in Peri-Urban Ghana Influence and Effects of Resource Inequalities. American Journal of Agriculture and Forestry, 2(3), 79. http://doi.org/10.11648/j.ajaf.20140203.14

Villabón, C. C. C. (2012). Gender Differences in Agricultural Productivity A crosssectional household survey data. Universitas Osloensis Mdcccxi. Retrieved from http://www.duo.uio.no/

Waris, A., Nirmala, B., \& Kumar, S. A. (2016). Gender gap and female workforce participation in agriculture in Andhra Pradesh, India. African Journal of Agricultural Research, 11(9), 769-778. http://doi.org/10.5897/AJAR2013.7683 